\title{
RUMAH BELAJAR: THE SOCIETAL-BASED MANAGEMENT OF EDUCATION
}

\author{
Taufiqurrohman ${ }^{1)}$, Achmad Badarudin Latif ${ }^{2)}$, Lisnaatul Faundiyah ${ }^{3)}$, Desi Astutik ${ }^{4)}$ \\ ${ }^{1}$ Faculty of Tarbiyah and Teacher Science, Islamic University of Nahdlatul Ulama \\ Jepara \\ email: ufiq@unisnu.ac.id \\ ${ }^{2}$ State Vocational School 1 Kedung Jepara \\ email: ahmadlatif22@yahoo.com \\ ${ }^{3}$ Rumah Belajar Cemerlang Jepara \\ email: ziyah.faunziyah@gmail.com \\ ${ }^{4}$ Rumah Belajar Imara Jepara \\ email: semut.astut@gmail.com
}

Key word:

Rumah Belajar,

Societal-Based

Management,

Beneficial Courses

\begin{abstract}
This article shares an alternative management for holding a nonformal education in the grassroot level of community. Such alternative complement education in Indonesia is commonly what socalled Rumah Belajar (House of Learning). This article parses two samples of it in Jepara. They are managed as well so that it does not reduce the learning quality. It does not only teach hard skill but, more of that, also teach soft skill to the students. It is based on societal benefit in its operation. It does not charge the students with any fees. Instead, it often gives such course equipments to the needy students. The teachers' spirit of this course is to be beneficial to others. Below is their complete profile.
\end{abstract}

\section{Kata Kunci \\ Rumah belajar, \\ Manajemen berbasis sosial, kursus}

\begin{abstract}
Abstrak
Artikel ini bercerita tentang sebuah manajemen alternatif untuk menyelenggarakan pendidikan non-formal di tingkat masyarakat akar rumput. Pendidikan pelengkap alternatif di Indonesia ini biasa disebut Rumah Belajar (House of Learning). Artikel ini menyajikan dua buah sampel di Jepara. Rumah Belajar yang dikelola dengan baik sehingga tidak mengurangi kualitas belajar. Rumah Belajar tidak hanya mengajarkan keterampilan umum tapi, lebih dari itu, juga mengajarkan soft skill kepada para siswa. Hal ini didasarkan pada manfaat sosial dalam operasinya. Para siswa yang belajar di Rumah Belajar tidak dikenakan biaya. Bahkan, siswa diberi kursus yang dibutuhkan. Semangat guru kursus ini bermanfaat bagi orang lain. Berikut adalah profil lengkap mereka.
\end{abstract}




\section{INTRODUCTION}

National Order (Undang-undang) number 20 year 2003 on National Education System (Sistem Pendidikan Nasional) says that education is the intended and planned effort to hold learning atmosphere and process so that the students can actively upgrade their potentials to own the power of religious spirituality, self-control, positive personality, intelligence, noble behavior, and needed skills for the importance of himself, of society, of nation and of country. In fact, the domain of education can include the above definition is not only formal education but also non-formal education and informal education. It is due to their intention and certain efforts to upgrade pupil's personality or knowledge.

One of the educating efforts is through non-formal education. It has different characteristics from those owned by formal education. Its learning is not conducted by an education or training institution. It also does not lead to certification. But it has learning objectives, learning time or learning support so that even its common daily activities in learning can be their competencies too (Maier, p.77-86).

Based on the understanding above, there must be many non-formal education organizers in our societies. One of them is
Rumah Belajar (House of Learning). It is such one place for studying together taught by some volunteers whom we usually call them as teachers. The students are not charged by any school fees and the teachers do not get salary. One district in Central Java that has such good situation on this kind of education is Jepara. This article, in this occasion, are exploring two of the Rumah Belajar in Jepara, namely Rumah Belajar Cemerlang (RB Cemerlang) and Rumah Belajar Imara (RB Imara).

\section{METHODOLOGY}

This article is distinguished on its character in parsing one study case attached on two non-formal education organizers. So it uses Case Study Observational Research although this article is for community dedication. That's why observing the detail of the object, in this case RB Cemerlang and RB Imara, are what the observers need to do (Morgan et.al., 2017, p. 1060-1068).

The observers, as the advisors of both RBs too, here are the first and the second writer while being helped by the third as the founder of $\mathrm{RB}$ Cemerlang and the fourth writer as the founder of the $\mathrm{RB}$ Imara. Thus, the article here is the result of the mixed observation on such case. 


\section{FINDINGS AND DISCUSSION}

As one comparison, (Nath, Sylva and Grimes, 1999, p.5-26) has ever done one research in Bangladesh on the virtue of non-formal education rather than the formal one in raising rural children's life skill and writing. They said that of the four components of basic education, BRAC (Bangladesh Rural Advancement Community) children did significantly better in life skills and writing than peers in formal schools. Apart from other researches on it, still it can be one inference that non-formal education cannot be seen undeterminant for children's education progress.

In case with what has been done by two Rumah Belajar (RB) in Jepara, namely RB Cemerlang and RB Imara, they used such creative management of education and also creative process of learning. With the limit of finance, they have unlimited creativity to hold good education for society, especially for children.

The first one is on the background of the establishment of their house of learning. RB Cemerlang was established on July 2016 by the intention to help people around Suwawal to get additional education outside formal school. It is based on pure societal value so that it does not give charge for students. While RB Imara was established on December 2016 by the motivation to assist people around Watuaji Keling to have place for reading books and studying together.

Their sincere motivation then was responded by children, at first, positively. Some children in Suwawal started to learn anything from volunteers of RB Cemerlang. It also what happened to some children in Watuaji too.

Their model of learning is purely what are done at non-formal education. Exactly the same with the characteristics parsed by Hiryanto, M.Si. (2009, p.1-10) in which amongst them are developing behavior and personality progress as well as mastery of knowledge and personality skill, both RBs has creativities in learning model. Although they still help children in their subjects at school, but principally they conduct models of soft skill progress as well as developing children's potentials.

They give chance for children to develop their potentials as well as their soft skill. They often share not only how to make some simple handicrafts but also how to behave before children's parents and older people. In simple word, they have the abundance of learning objects. Yet, those learning objects are done by fun model of learning. No force is conducted at both RBs. It is like research on a succeeded non-formal education in Sidrap South Sulawesi to marginal women in a 
rural area has been conducted by Tahir (2011, p.313-321) that $80 \%$ of the students loved to prefer drawing, music and film method than the serious ones because they can feel and express their creativity.

These are the programs of $\mathrm{RB}$ Cemerlang:

1) Creation Day;

2) Bimbingan Belajar (School's Homework Assistance);

3) Library.

The first one holds anything by creative touch. It is like how to read the Qur'an better, how to type better by computer, how to understand movies, how to make origamy, traditional games, outbound, etc. The second one is helping children understand subjects conveyed at formal schools. Then the third one is reading books together based on their interesting topics.

While RB Imara's programs are basically the same with what owned by RB Cemerlang. But its location is more rural than in RB Cemerlang.

They also often use nature and living environment as their class. Periodically the students are taught how to plant many plants and trees, how to treat those plants, how to make garden, etc. Outbound and traditional games are often be played by them at those places.

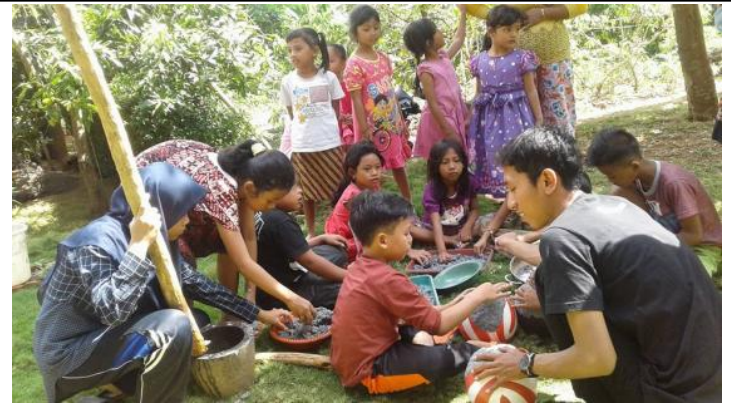

Picture 1: The volunteers of RB Imara were sharing how to make masks from unused papers at one volunteer's house's yard.

Although their education charges no fee to children, their programs are in wellgrowth because in short time, their existence and sincere dedication was known by either people in that village or people outside. Even, village apparatus support them. Sometimes those people gave some equipments to children's study for the RBs. Besides, their well-growth is caused too by their involvement in local Jepara government's program like in Festival Literasi Jepara (Literacy Festival Jepara). It made them exist both in online and newspaper. Both have active display and report of activities in social medias like Facebook and Instagram. Beside that, RB Cemerlang has an account for book donation officially from government. 


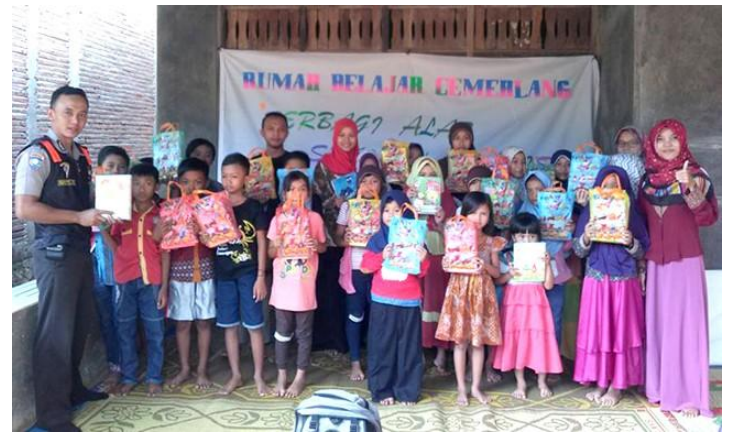

Picture 2: RB Cemerlang has been issued in Jawa Pos newspaper either printed or online one that the volunteers have changed the RB Cemerlang founder's living room to be a library. Look up: https://www.jawapos.com/radarkudus/read /2017/10/12/19147/sulap-ruang-tamu-jadiperpustakaan-mini

Both RBs are also active in their village's programs. They are one with their society. It gives them big chance to empower children of the village. Take for example village program on commemoration of Independence Day. They are hand in hand with the students and society to make the program succeeded. It is like the volunteers/the teachers of the RBs who made many creativities for their students to have the carnival at that day more colorful. It is in line with what has been written by Ganiem (2017, p.239-255) that empowerment of urban poor women which has been done through non-formal education by utilizing existing social forces in society has positive impact because it is relevant to the needs of local communities and optimizes the resources owned by local communities.
Such societal-based management of education has made their non-formal education own strong position in their village, even in Jepara. Take for example RB Cemerlang. Beside Suwawal as the central basecamp, they have two branches, namely in Wonorejo and in Sinanggul, just in one and a half year. The volunteers of course are more now. It strengthen the thesis that their societal-based management of education is beneficial and well-accepted by society.

\section{CONCLUSION}

Rumah Belajar, exemplified by both $\mathrm{RBs}$, has proven that non-formal education has a big role in people's life. Such societal-based management of education has won people's heart. It has given many benefits for the journey of their life. Their fun and natural methods in learning is memorized by the students.

\section{REFERENCE}

Ganiem, Leila Mona. (2017). Pemberdayaan Perempuan Miskin Kota. Jurnal ASPIKOM, 3(2): 239255.

Hiryanto, M.Si. 2009. Meningkatkan Efektifitas Pendidikan Nonformal dalam Pengembangan Kualitas Manusia. Materi Seminar Peran PKBM dalam Peningkatan Kualitas 


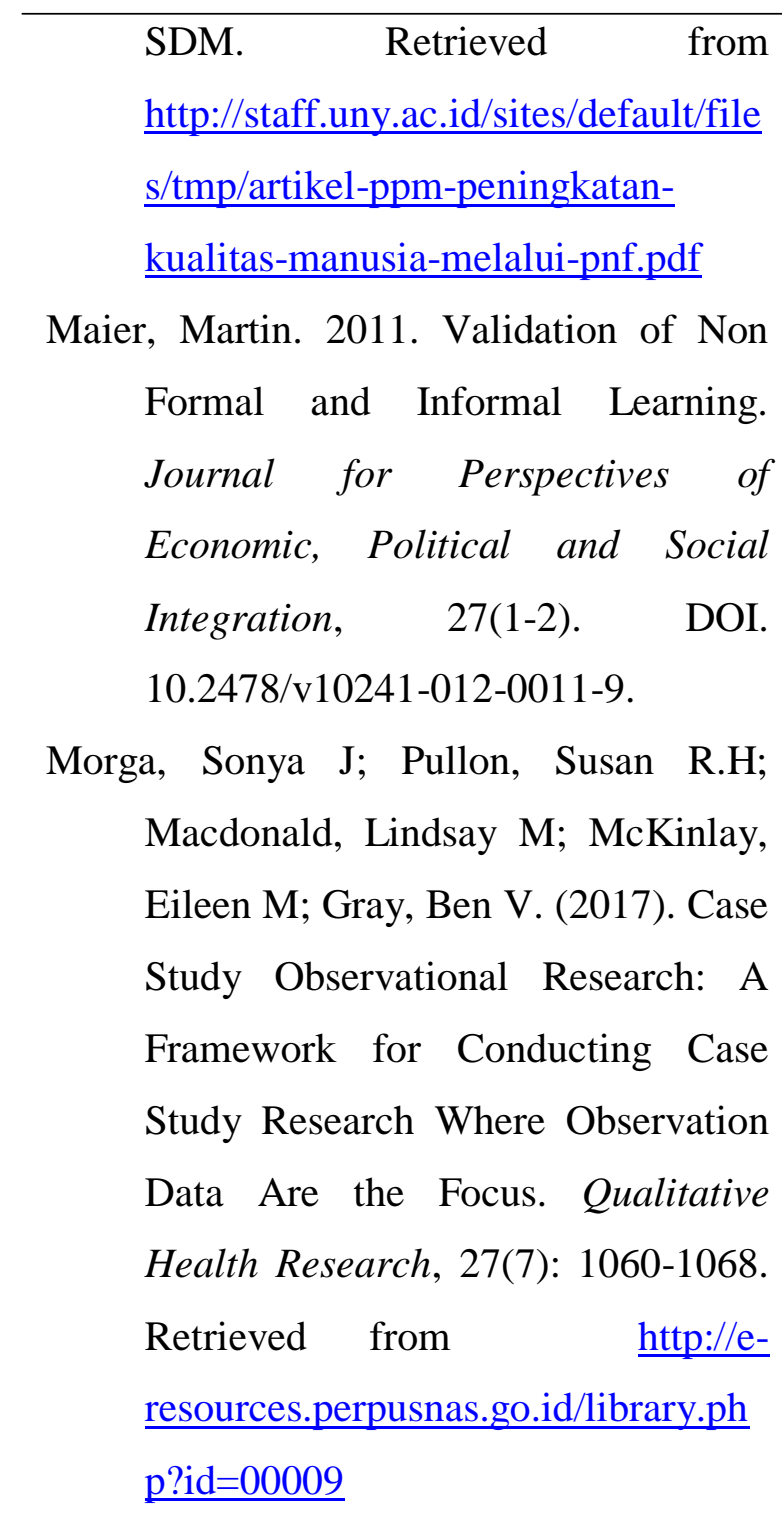

Nath, Samir R.; Silva, Kathy; Grimes, Janice. (1999). Rising Basic Education Levels in Rural Bangladesh: The Impact of A NonFormal Education Programme. International Review of Education, 45(1): 5-26.

Pendiri Rumah Belajar Cemerlang Sulap Ruang Tamu Jadi Perpustakaan Mini. Retrieved from: https://www.jawapos.com/radarkudu s/read/2017/10/12/19147/sulap-

$\underline{\text { ruang-tamu-jadi-perpustakaan-mini }}$

Tahir, Ratnawati. (2011). Pendidikan Alternatif untuk Perempuan Marginal di Pedesaan. Jurnal Ilmu Pendidikan, 17(4): 313-321.

Undang-undang Republik Indonesia Nomor 20 Tahun 2003 Tentang Sistem Pendidikan Nasional. Retrieved from: https://kemenag.go.id/file/dokumen /UU2003.pdf 